\title{
Author Correction: Hesperidin and capsaicin, but not the combination, prevent hepatic steatosis and other metabolic syndrome-related alterations in western diet-fed rats
}

\author{
Andrea Mosqueda-Solís, Juana Sánchez, Bárbara Reynés, Mariona Palou, María P. Portillo, \\ Andreu Palou \& Catalina Picó
}

Correction to: Scientific Reports https://doi.org/10.1038/s41598-018-32875-4, published online 10 October 2018

The Acknowledgements section in this Article is incomplete.

“This work was supported by the Spanish Government (AGL2015-67019-P), and the Instituto de Salud Carlos III, Centro de Investigación Biomédica en Red Fisiopatología de la Obesidad y Nutrición, CIBERobn. Laboratory of Molecular Biology, Nutrition and Biotechnology is a member of the European Research Network of Excellence NuGO (The European Nutrigenomics Organization, EU Contract: no. FP6-506360). A. Mosqueda-Solís is a recipient of a doctoral fellowship from the CONACYT (Mexico)."

should read:

"This work was supported by the Spanish Government (AGL2015-67019-P; MINECO/FEDER, UE), and the Instituto de Salud Carlos III, Centro de Investigación Biomédica en Red Fisiopatología de la Obesidad y Nutrición, CIBERobn. Laboratory of Molecular Biology, Nutrition and Biotechnology is a member of the European Research Network of Excellence NuGO (The European Nutrigenomics Organization, EU Contract: no. FP6-506360). A. Mosqueda-Solís is a recipient of a doctoral fellowship from the CONACYT (Mexico)."

(i) Open Access This article is licensed under a Creative Commons Attribution 4.0 International License, which permits use, sharing, adaptation, distribution and reproduction in any medium or format, as long as you give appropriate credit to the original author(s) and the source, provide a link to the Creative Commons license, and indicate if changes were made. The images or other third party material in this article are included in the article's Creative Commons license, unless indicated otherwise in a credit line to the material. If material is not included in the article's Creative Commons license and your intended use is not permitted by statutory regulation or exceeds the permitted use, you will need to obtain permission directly from the copyright holder. To view a copy of this license, visit http://creativecommons.org/licenses/by/4.0/.

(C) The Author(s) 2020 